\title{
Scaffolding Sociodramatic Play in the Preschool Classroom: The Teacher's Role
}

\author{
P. L. N. Randima Rajapaksha \\ Dept. of Early Childhood and Primary Education, Faculty of Education \\ The Open University of Sri Lanka, Srilanka; Email: plran@ou.ac.lk
}

\author{
Doi:10.5901/mjss.2016.v7n4p689
}

\begin{abstract}
Preschool children best learn through play. Among different play types sociodramatic play takes a crucial role during preschool years. Adults play a major in facilitating sociodramatic play for learning and development in preschool children. This study attempted to examine the role of the teacher in scaffolding the sociodramatic play activities implemented in the preschool classroom. The study employed Observations, interviews and reflective journal as the data collection instruments under qualitative approach. The study conducted a sociodramatic play intervention for a sample of 25 children aged from 3-5 in a preschool located in Colombo district under four themes. The observations which were carried out throughout 4 weeks were videotaped and documented via field notes. The data analyzing was done from the beginning based on descriptive analysis. The intervention identified that when the children are not engaging in the sociodramatic play activities much due to their limited experiences, the teacher has to be a play leader. When the children improve their interest in engaging in the sociodramatic play activities the teacher has to shift her role to co-player role. Thus the study concluded that the intervention identified pedagogical strategies for the teacher to scaffold the sociodramatic play activities in the preschool classroom.
\end{abstract}

Keywords: Preschool Teacher Role, Sociodramatic play, Early Childhood Education, Preschool Children

\section{Introduction}

In Sri Lanka, it is identifies that the early childhood education centers should not be places where something is taught to the child but centres with multiple activities for the overall development of personality including child's education; moreover, those conducting preschool programmes should be properly trained in child development of children between 3-5 years of age (EFA National Plan 2004: 35). Producing preschool classrooms that are warm and welcoming, while still fostering the academic, social, and emotional growth of students is important to establishing a positive first school experience for young learners as a beginning to their academic careers. In order to do so, play must still be considered a valued learning tool for students in their early child development (Schroeder, 2007).

In preschool years children engage in different forms of play including social, parallel, sociodramatic and locomotor play. Among the different forms of play sociodramatic play is highlighted as most common and important type of play during 3-5 years old. Sociodramatic play, in which children use objects as props to develop story episodes that involve other children, is seen increasingly as the children progress through this age period (Morgenthaler, 1998).

As Smilansky (1990) defined, sociodramatic play is a cooperation of at least two children, taking on roles in which they pretend to be someone else both verbally and in terms of acts performed. There are two basic elements to sociodramatic play: imitation and make-believe; imitation includes both actions and speech patterns and make-believe depends heavily on verbalization. It offers rich opportunities for children to develop abstract thinking (Piaget, 1962), define their understandings about the world (McCain, Mustard, \& Shanker, 2007), solve problems in a safe context (Smilansky \& Sheftaya, 1990), have a sense of control over what they experience or are doing (Piaget, 1962), and learn how to relate to their peers in a positive way (Saracho \& Spodek, 2003).

Adults can assist children in extending their play themes and interests, enrich their language and plot development, and facilitate as children explore and practice literacy. However, deciding when and how to intervene can be challenging (Cooper and Dever, 2001). Many early childhood teachers fail to provide support for children in play (Stantan-Chapman, 2014). This may lead to children not reaching their full potential which is often referred to as the "early childhood error" (Bredekamp 2013; Bredekamp and Rosegrant 1992). Kontos (1999) described the early childhood error occurs when early childhood educators prepare an appropriate, stimulating environment for young children but then stand back and fail to follow-up with guidance scaffolding or supportive responsive interactions with children as they play. 


\subsection{Significance of the study}

It is significant for the preschool teachers to obtain more awareness on how to integrate play into the preschool activities. This study would provide more knowledge, skills and strategies to preschool teachers on integrating sociodramatic play in the preschool classroom learning activities. Further, the other stake holders such as parents, principals, coordinators, early childhood officers and managers of preschools would be given the opportunity to understand how to provide more opportunities for children to experience such valuable playful experiences in the preschool classroom.

\section{Literature Review}

\subsection{Teacher's role in promoting sociodramatic play}

Adults play an important role in children's sociodramatic play. They can assist children in extending their play themes and interests, enrich their language and plot development, and facilitate as children explore and practice literacy. According to Vygotsky (1978), children engage in sociodramatic play as they wish to imitate adults' roles and perform their activities that the child is too young to attempt in their real lives. Vygotsky (1978) believed adult interactions can facilitate children's development within their zone of proximal development. A child's "zone of proximal development" is the range of tasks that the child can perform with guidance from others but cannot yet perform independently (Yellin et al., 2004). Bruner (1986) used the term scaffold as a metaphor to describe adults contribution to children's development and learning. Scaffolds are support mechanisms that teachers, parents, and others provide to help children successfully perform a task within their zones of proximal development.

Co-players and play leaders take active roles in children's socio-dramatic play ( Cooper and Dever, 2001). According to Meacham et al. (2014), the difference between the co-player role and the play leader role is the degree of control over the course of the play. In the play leader role, teachers indirectly direct and redirect the children's play still using pretend talk. The teachers arrange the play settings and initiate the literacy-related play. Teachers influence the play plots by introducing new elements into the play to facilitate the play as a play leader. In contrast, in the co-player role, teachers take a minimal play role. The co-player role encourages the children's meta- and pretend play conversation while the play leader role supports improving the quality of the sociodramatic play including detailed characterization and sophisticated plot development (Meacham et al., 2014).

In addition, teachers can create scaffolds by modeling or demonstrate a procedure, guide children through a task, ask questions, break complex tasks into smaller steps, and supply pieces of information (Bluiett, 2009), by provision of time, space, and materials (Sinha, 2012; Hoorn et al. 2003; and Howard and McInnes, 2013) and giving suggestions for use of materials (Kontos, 1999; McWilliam and Casey, 2008). As children gain knowledge and experience about how to perform a task, teachers can gradually withdraw their support so that children make the transition from external social interaction to internalized, independent functioning (Bluiett, 2009).

\section{Objective and the Research Questions of the Study}

The main objective of this study was to examine the preschool teacher's role in scaffolding the socio-dramatic play in the preschool classroom. To achieve this objective the following research questions were formulated.

1. How does the teacher play her role to scaffold sociodramatic play activities in the intervention implemented in the preschool classroom?

2. What problems the do teacher face in scaffolding the sociodramatic play activities in the intervention implemented in the preschool classroom?

\section{Method}

Cohen, Manion, and Morrison (2003) stated that the primary focus of qualitative research is that of understanding the ways in which individuals create, interpret and modify the world in which they live. Moreover, qualitative researchers often use multiple forms of data in a single study such as observations, interviews, objects, artifacts, audiovisual materials, electronic documents, and anything else that can help them answer their research questions (Bluiett, 2009). Because this study focused on the teacher's role and interaction of the teacher with the preschool children in the sociodramatic play setting using multiple forms of data collection, such was the method for this study.

The setting of this study was a preschool situated in the Colombo district. There were two head teachers and an 
assistant teacher to conduct activities in the preschool. In the preschool, there were 50 children including 24 in the upper class (4-5 age) and 26 children in the lower class (3-4 age). The sample included 12 children from upper class and 13 from lower class based on purposive sampling as the total class couldn't be taken at the same time. From the lower class, the sample included 6 boys and 7 girls and from the upper class there were 6 boys and 6 girls. The class teacher of the lower class was included in the teacher sample.

\subsection{Instruments}

The researcher used multiple methods of data collection such as observations, field notes, reflective journal, and semistructured interviews as strategies to add depth and richness to the study (Steenberg, 2007). All the observations were video-taped and then documented via field notes after the sessions. The semi-structured interview was conducted with the teacher before and after the sociodramatic play intervention. The teacher was asked to keep a reflective journal focusing on her role in the play intervention.

\subsection{Intervention}

The sociodramatic play intervention was developed and implemented for about 4 weeks. The intervention was designed by the researcher. The research implemented the sociodramatic play intervention collaboratively with the teacher. Before the intervention the researcher instructed the teacher on the sociodramatic play and obtained the consent of the parents of children and preschool teacher to conduct the research. All 25 children in the sample took part in the intervention as 2 groups. One group included 12 and other 13 representing both sex and age levels. Since their primary language was Sinhala, the intervention was conducted in the Sinhala language. Four themes, The Shop, The Market, The Dispensary and The School Classroom were selected for the intervention based on the year plan. The sessions were conducted for 20 minutes each (Steenberg, 2007) in the morning. For each theme, the play materials were decided and collected in advance.

\subsection{Analysis of the Data}

The data analysis was carried out in several stages.Initially, the video tapes were viewed over and over again focusing each child in relation to the research questions (Bluiett, 2009). While the videotapes were viewed the conversations were noted down. Finally, all the data gathered through instruments were trangulated. In order to analyze the data, the descriptive analysis method was employed.

\section{Results and Discussion}

\subsection{Teacher's role in scaffolding sociodramatic play intervention in the classroom.}

During the first theme, the teacher's involvement was high in the play. It was noticed that the teacher attempted to engage in the play as one of the characters in the play because the children were little backward in engaging in the play. She pretended to be the mother who goes to the clothing shop to buy clothes for her sons and daughters in this theme. The following conversation explains how the teacher commenced the play theme "The Shop".

Teacher: "Now my children, we are going to do a new play game today. I think you might have gone shopping with your mothers. Isn't it? Ok. Now we are going shopping to buy clothes for us. Who would like to be the Mudalali of our shop?

$\mathrm{ML}$ raises his hand.

Teacher: "Right. ML is the Mudalali, good. Then KV can be the helper as there should be someone to help our Mudalali. And I am the mother, you two are my sons and you two are my daughters. Shall we start our play?"

This discussion seemed a very good technique to make the children engage in the play session at the beginning since it made children aware of the roles they had to play. It was seen that the teacher had to take the leading role in the play since this was a new experience for them as a classroom activity. The teacher initiated the play asking "Mudalali we came to buy some clothes for my sons and daughters. Can you help us?". This helped the children to start engaging in conversation in the play in order to continue. It seemed that the teacher gave some ideas to the children to continue the play. For instance, she told the boy who played the shop owner's role, "Let's see a frock for my daughter", in order to get him involve in the role. 
Likewise, the teacher gave comments such as "Mudalali, this is too small", and asked for support "Mudalai do you have clothes to wear during cold days?", "Ok, Let's try this shirt. Mudalali this one is OK for my son. How much is this?". It was highlighted that the teacher made a significant influence on each child to involve them in the play. As well, it was identified that the children responded to their teacher as they would respond to their mothers. It could be identified that the teacher attempted to indirectly direct and redirected the children's play still using pretend talk as a play leader (Meacham et al., 2014).

It was observed that in her role as a play- leader in the play she had to use more strategies such as a lot of directions to children to make them participate in the play. Further, it was seen that the teacher didn't use orders and commands with the children but she tried to make the children think of what to do next according to their roles using pretend talk.

During the second theme, it was apparent that the teacher made attempts to create scaffolds by modeling or demonstrating a procedure, guiding children through a task, asking questions, breaking complex tasks into smaller steps, and supplying pieces of information. As Bluiett, (2009) explained when children gained knowledge and experience about how to perform the play, she gradually withdrew her support so that children could make the transition from external social interaction to internalized, independent functioning.

The teacher's influence on the children's play was minimized gradually during the Market theme. It was observed that she tried to direct the children to their roles by asking questions and giving feedback. When the Market theme was implemented the children were a little familiar also with the play and their roles since it was similar to the previous theme. The following conversation shows how the teacher gradually shifted her role from play- leader to co-player role.

Teacher: "I think now it's time for us to go shopping. We have a clothing shop. Shoe shop, a teddy bear shop, and accessories shop in our market. So let's go shopping."

Teacher: "Mudalali, the customers have come. I think we should help them to choose."

When SS, KV, and SN go to NT's accessories shop, the teacher says,

Teacher"NT, SS is asking for a red colored bangle".

When TU and HK are standing silently in one instance she says,

Teacher: "TU, would you like to buy a pair of shoes for yourself? go and choose one."

And says to HR who is the shop owner,

Teacher: "Now Mudalai, we better help TU to select shoes, OK?

Likewise, throughout the session, it was demonstrated that the teacher tried to help children to imitate their roles and persist in the role very much by giving ideas on the duties of their role and feedback.

In the Dispensary theme, the teacher's direction was slightly less. It was seen that when the teacher's role was gradually shifting to co-player the children's participation slightly improved in the Dispensary theme. The teacher attempted to direct the children as a co-player. For instance, she informed the doctor, "Doctor, I think we need to examine the patient. You can use the stethoscope and can ask him to breathe." and she said "We need to check him more right doctor? Nurse aunty, help the doctor to put him on the bed." Finally, she asked,"Doctor, how is your patient now? Did you put medicine?". This direction helped the children to persist in their role throughout the session.

It was seen that as a scaffold in guiding students' learning within the zone of proximal development the teacher attempted to mediate children through social interaction by letting all children to interact with each other, provided support based on feedback and that support also varied according to each child's level of participation. It was further mentioned in the teacher's reflection as follows,

Now children have an idea of the play. Today ML, SS, and HR did their roles well. So I don't want to direct them more. But still TU, MN, HK, KV, and NT were a little backward. I had to guide them more in their roles. Especially in the doctor's role they were a little backward. So I guided them very much giving more ideas and feedback. (Teacher's reflective journal, 01.12.2014)

As the teacher indicated in her reflections when children increase their participation in the play the teacher gradually paid more attention to those who were still at a lower participation level.

Further, the teacher did a demonstration of a teacher by acting as a role model before starting the School classroom theme. It was seen that the demonstration made a clearer understanding of the role of teacher when observing the children's imitative role in the play. it was revealed that the teacher's strategies to be a character in the sociodramatic 
play intervention as the play-leader and shifting her role to co-player by minimizing her support created more opportunities for children to gain awareness and experiences about the sociodramatic play. In addition her scaffolding strategies such as preparing the play scene and materials, giving ideas, commends, feedback, asking questions, discussing on the scene and demonstrating roles helped the children to engage in the play throughout the sessions.

\subsection{Problems Encountered by the Teacher during the Intervention.}

It was identified during the observation and the interview that the teacher faced some problems in the sociodramatic play intervention. The teacher indicated that during the first theme she faced difficulties in supporting children to participate in the play activity in her role as a play leader. She revealed that it was a little difficult for her to take all children to the play. She further mentioned that the reason for this problem was the lack of experience of sociodramatic play as a classroom activity in her preschool.

The following are some of the teacher's views expressed during the interview on her difficulties after the intervention.

"At the beginning, it was a little difficult for me to take all children in the play. I wasn't used to that kind of role because I had to act a role in the play and after some time I had to improve their participation in the play. This was a little difficult for me to the first theme."

Moreover, the teacher indicated that it was difficult for her to arrange the environment for the activity. The teacher indicated that she faced problems in selecting a variety of play materials for children from day to day. This was further identified during the intervention that children didn't like to use the same materials repeatedly. It was seen that when the play materials were changed often they showed much enthusiasm to use them and participate in the play.

This was further observed in her reflections as follows;

Today at the beginning I felt that the children didn't show much interest to use the play materials. They didn't like to use the same materials. So I changed the play materials and added some more materials relevant to the dispensary. After that the children showed more interest in participating. But it is difficult to provide them different play materials every day. (Teacher's reflective journal, 01.12.2014)

It was revealed that lack of awareness about the sociodramatic play, children's lack of experience in sociodramatic play as a classroom activity and lack of sufficient play materials relevant to each theme for sociodramatic play in the preschool were the problems the teacher faced during the intervention.

\section{Conclusions}

The sociodramatic play intervention concluded that children showed a greater interest in sociodramatic play when compared with the other usual classroom activities. The sociodramatic play intervention identified the nature of the teacher's role in scaffolding sociodramatic play. The play leader and the co player roles of the teacher actively scafollded the sociodramatic play intervention (Cooper \& Dever, 2001 and Meacham et al., 2014). The intervention explicated concrete pedagogic strategies for the teacher working with children in sociodramatic play. further, the intervention concluded the teaher's awareness, experieces and availability of a variety of play materials also influence the teacher's role in scaffolding the sociodramatic play in the classroom. Therefore more awareness, guidance and emphasis should be given to the teacher as well as the preschool management on scafoolding the sociodramatic play.

\section{References}

Bluiett, T. E. (2009). Sociodramatic play and the potentials of early language development of preschool children, (doctoral dissertation). [Online] Available: http://acumen.lib.ua.edu/content/u0015/0000001/0000137/u0015_0000001_0000137.pdf

Bredekamp, S. (2013). Effective practices in early childhood education: Building a foundation. Upper Saddle River, NJ: Pearson.

Bredekamp, S., \& Rosegrant, T. (1992). Reaching potentials: Appropriate curriculum and assessment for young children (Vol. 1). Washington, DC: National Association for the Education of Young Children.

Bruner, J. (1986). Play Thought and Language. In PROSPECTS: Quarterly Review of Education. Paris, France: UNESCO. [Online] Available: http://link.springer.com/article/10.1007/BF02197974\#page-1

Cohen, L., Manion, L., \& Morrison, K. (2003).Research methods in Education.(Fifth edition).New York. RoutledgeFalmer.

Cooper, J. \& Dever, M. T., (2001). Sociodramatic play as a vehicle for integration in first- grade curriculum. Young children, 56 (3), 58-63 [Online] Available: http://digitalcommons.usu.edu/cgi/viewcontent.cgi?article=1010\&context=teal_facpub 
Hoorn, J. V., Nourot, P. M., Scales, B., \& Alward, K. R. (2003). Play at the center of the curriculum. Upper Saddle River, New Jersey: Pearson.

Howard, J., \& McInnes, K. (2013). The essence of play: A practice companion for professionals working with children and young people. New York: Routledge

Kontos, S. (1999). Preschool teachers' talk, roles, and activity settings during free play. Early Childhood Research Quarterly, 14(3), 363382. [Online] Available: http://dx.doi.org/10.1016/S0885-2006(99)00016-2

McCain, M., Mustard, F., \& Shanker, S. (2007). Early years study 2: Putting science into action. Toronto, ON: Council for Early Child Development.

McWilliam, R. A., \& Casey, A. M. (2008). Engagement of every child in the preschool classroom. Baltimore, MD: Paul H. Brookes Publishing Company.

Meacham, S., Vukelich, C., Myae, H., Buell, M. (2014). Preschool teachers' questioning in sociodramatic play. Early Childhood Research Quarterly, 29(4), DOI: 10.1016/j.ecresq.2014.07.001

Ministry of Human Resource Development, Education \& Cultural Affairs. (2004). Education for All National Plan Sri Lanka. Ministry of Human Resource Development, Education \& Cultural Affairs, Sri Lanka.

Morgenthaler, S. K. (1998). The meanings in play with objects. In Play from birth to twelve and beyond: contexts, perspectives, and meanings, 359-367.

Piaget, J. (1962). The Psychology of the Child. New York: Basic Books.

Saracho, O. \& Spodek, B. (Eds.). (2003). Contemporary perspectives on early childhood curriculum. Greenwich, CT: Information Age Publishing.

Schroeder, K. (2007). Kids need play. The Education Digest, 72(5), 73-74.

Sinha, J. M. (2012). The land of make-believe: Using sociodramatic play to increase kindergartners' self-regulatory abilities. ETD Collection for Fordham University. Paper AAI3544140. [Online] Available: http://fordham.bepress.com/dissertations/AAI3544140

Smilansky, S. (1990). Sociodramatic play: Its relevance to behavior and achievement in school. In E. Klugman \& S. Smilansky (Eds.), Children's play and learning: Perspectives and policy implications, (pp. 18-42). New York: Teachers College Press.

Stanton-Chapman, T. L. (2014). Promoting Positive Peer Interactions in the Preschool Classroom: The Role and the Responsibility of the Teacher in Supporting Children's Sociodramatic Play. Early Childhood Education Journal, 43(2) 99-107. Doi 10.1007/s10643014-0635-8

Steenberg, R. K. (2007). The applicability of fairy-tale based sociodramatic play in developing social skills among high-functioning children with autism. [Online] Available: www.nailsearch.com/pdf/fairy-tale-high.html

Vygotsky, L. (1978). Mind in Society, Cambridge, Mass, Harvard University Press.

Yellin, D., Blake, M. E., \& Devries, B. A. (2004). Integrating the language arts. Scottsdale, AZ: Holcomb Hathaway. York: Plenum. 